„Etnografia Polska”, t. LXV, 2021, z. 1-2

PL ISSN 0071-1861; e-ISSN: 2719-6534

DOI: $10.23858 /$ EP65.2021.2699

CC BY 4.0

ALINA LANDOWSKA

SWPS Uniwersytet Humanistycznospołeczny, Warszawa

\title{
O RELACJACH MIĘDZY KOOPERACJĄ I MORALNOŚCIĄ - W KIERUNKU NOWEJ ANTROPOLOGII MORALNOŚCI
}

\section{WSTĘP}

Od dawna antropologia poszukiwała odpowiedzi na pytanie, czym jest moralność i w jakim zakresie jest współdzielona przez wszystkich ludzi. Edvard Westermarck $(1906,1932)$ i Robert Marett $(1916,1931)$ jako jedni z pierwszych antropologów w centrum swoich prac stawiali badania nad ewolucją i zróżnicowaniem moralności w różnych społeczeństwach. Wydaje się jednak, że największy wpływ na antropologię wywarły poglądy francuskiego socjologa Émilea Durkheima, który zdominował dyskurs europejski, oraz amerykańskiego antropologa o niemieckim pochodzeniu - Franza Boasa, który zdominował dyskurs amerykański. Durkheim zaproponował zastąpienie spekulatywnej filozofii moralnej pozytywistyczną nauką o faktach moralnych. Wychodząc od analizy życia religijnego jako pewnego porządku społecznego (Durkheim 2010 [1912]), przyjął zasady dobrego zachowania jako punkt wyjścia swoich rozważań o moralności. Twierdził, że ludzie potrzebują relacji z Dobrem, aby być dobrymi, i próbował to Dobro dookreślić. Uznał, że jest nim społeczeństwo, ponieważ związane z nim rytuały pozwalają jednostkom na doświadczanie rzeczywistości społecznej w taki sposób, że przynosi im to swoistą radość i stanowi znacznie więcej niż jedynie sumę doświadczeń pojedynczych jednostek. Durkheim doszedł do wniosku, że nowoczesne państwo powinno ustanowić rytuały i zaprojektować świecką religię, aby zasady postępowania niezbędne do zachowania harmonii i solidarności były powszechnie przyjmowane i dobrowolnie przestrzegane. Właściwe zasady i wartości, jego zdaniem, powinny być wpajane zarówno poprzez system edukacji, jak i regulowane przez zbiorowe życie obywatelskie (Durkheim 2015 [1925], 1957 [1937]).

Moralne koncepcje Durkheima były podobne do tych sformułowanych przez Immanuela Kanta. Mechanistyczno-socjologiczne podejście Durkheima wymagało pełnej sekularyzacji społeczeństwa, stawiając państwo w roli zarządcy społecznych praktyk. Podczas, gdy filozoficzne podejście Kanta koncentrowało się na problemach natury filozoficznej wynikających z relacji między człowiekiem jako częścią świata naturalnego a człowiekiem jako racjonalnym, wolnym podmiotem, durkheimowski człowiek, choć posiada podwójną egzystencję, to jednak nie ma dylematów. Dualizm jego egzystencji polega na niekontrolowanych i egoistycznych wpływach 
biologicznych z jednej strony, a z drugiej - na zdolności do prowadzenia życia społecznego, gdy jednostka jest włączona w sprawnie zorganizowane społeczeństwo. Uproszczony wymiar wolności u Durkheima sprowadza się do kwestii wyboru (mniej lub bardziej chętnego) dokonywanego przez jednostki, czyli robienia tego, czego i tak wymaga społeczeństwo. Życie społeczne to życie moralne, które stoi w jawnej opozycji do egoistycznego i biologicznie uwarunkowanego życia jednostki.

Ujęcie zaproponowane przez Boasa w oparciu na kontekstualnym rozumieniu kultury jest bardzo podobne. Skoro kultura jest zintegrowanym systemem symboli, idei i wartości, to poprzez interakcje pomiędzy jednostkami, które ją przejmują, urzeczywistnia się w ich sposobie myślenia, odczuwania czy działania (Benedict 2011). Autonomia kultur ma także za zadanie doprowadzić do integracji społecznej (analogicznie jak u Durkheima), a zasady moralne mają sprzyjać budowaniu solidarności. W zaprojektowanym przez Boasa życiu społeczno-kulturowym jednostka wydaje się znowu pozbawiona dylematów etycznych. Natomiast inaczej kwestie moralności ujmowali antropolodzy marksistowscy (Lukes 1985; Patterson 2009). W ich ujęciu istotne było wyjaśnienie, w jaki sposób grupy podporządkowane są skłaniane do respektowania zasad moralnych sprzecznych $\mathrm{z}$ ich interesami, ustanawianych przez grupy dominujące, albo w jaki sposób grupy podporządkowane realizują swój cichy opór bądź brutalny bunt, odzwierciedlające ich alternatywne systemy wartości. W konsekwencji moralność staje się wyrazem kolektywnej reprezentacji wartości w obrębie danej klasy dominującej bądź podporządkowanej.

Te główne paradygmaty - socjologiczny Durkheima i kulturalistyczny Boasa - nie ograniczyły jednak badań antropologów, na które złożyły się wnikliwe obserwacje życia społecznego, religijnego, politycznego czy gospodarczego różnych grup społecznych i formacji kulturowych (np. pokazały, jak osiąga się współpracę i jak jest ona regulowana za pomocą wspólnych norm i wartości). Stanowią one niekwestionowane źródło wiedzy o życiu etycznym tychże społeczności. Ale czy jest ono wystarczające? Antropologia rozumiejąca moralność jako przestrzeganie sankcjonowanych reguł postępowania być może powinna zainteresować się także wyjaśnianiem mechanizmów zachowania wynikającego z tych reguł, jak i ich omijaniem (Mattingly 2012). Ta kwestia wciąż pozostaje nierozwiązanym problemem, co zauważył m.in. Meyer Fortes (2009 [1987]). W 1962 roku filozof Abraham Edel (1962) narzekał, że „antropologia nie dostarczyła systematycznej koncepcji [moralności]" (Edel 1962, s.67) i unika "problemu moralności, określenia, czym jest, jakich znaków identyfikacyjnych należy szukać i jak zabrać się za ich mapowanie” (Edel 1962, s. 56). Należałoby spodziewać się, że dociekliwość i szczegółowość, charakterystyczne dla metod etnograficznych, dostarczą wiarygodnej i rzetelnej wiedzy o życiu moralnym, tak potrzebnej choćby w debacie filozoficznej, i pomogą zrozumieć skomplikowane życie etyczne różnych wspólnot. W 2002 roku antropolog James Laidlaw nadal ubolewał, że „[n]ie ma antropologii etyki [...] nie ma trwałej dziedziny badań i debaty. Nie ma wiążącej historii, którą potrafilibyśmy opowiedzieć o badaniu moralności w antropologii, tak jak robimy to w przypadku szeregu tematów, takich jak pokrewieństwo, gospodarka, państwo lub ciało" (2002, s. 311). 
Utrwalone zainteresowanie etyką jest dostrzegalne od przełomu tysiącleci, kiedy antropologia moralności wyszła znacznie poza badanie mechanizmów kontroli społecznej i enkulturacji, a jej przedstawiciele zaczęli brać udział w dyskusjach w obrębie filozofii moralnej. Istotne wydają się prace Jamesa Laidlawa (2002), Michaela Lambeka (2000) oraz Jamesa Faubiona (2001), które stały się inspiracją do wszechstronnego i produktywnego zaangażowania się badaczy w kwestie moralności i etyki (np. Cassaniti, Hickman 2014; Fassin 2012; Faubion 2001, 2011; Gehlen 2017; Heintz 2021; Howell 1997; Laidlaw 2013; Lambek 2008, 2010; Lear 2015; Mattingly, Throop 2018; Rajtar 2014; Zigon, Throop 2014; Zigon 2008). Zakres tych prac systematycznie zaczął poszerzać się o różne tradycje intelektualne zaczerpnięte $\mathrm{z}$ innych dyscyplin. Miało to na celu opracowanie aparatu pojęciowego i słownictwa w obrębie antropologii oraz pogłębienia ogólnego zrozumienia natury życia moralnego czy etycznego. Eksploracje te obejmują etykę cnót, filozofię języka potocznego i "genealogię etyki” Michela Foucaulta, oraz - w mniejszym stopniu i od niedawna - fenomenologie i psychologię eksperymentalną. To ewidentne ożywienie prowadzi do tego, co Didier Fassin (2012), James Laidlaw (2013) czy Michael Klenk (2019) nazywają „zwrotem etycznym” czy „zwrotem moralnym”.

Sytuacja ulega radykalnym przemianom, ponieważ moralność staje się także przedmiotem interdyscyplinarnych badań z zakresu nie tylko historycznie zaangażowanej filozofii czy - jak wykazano - antropologii, ale też teorii ewolucji (np. Tomasello 2016), genetyki i biologii (np. Nowak 2006), etologii (np. Eibl-Eibesfeldt 2007; Matsuzawa 2001), psychologii (np. Greene 2014, 2015; Haidt 2007; Haidt, Joseph 2004), neuronauki (np. Sinnott-Armstrong 2007) czy ekonomii (np. Axelrod 1984).

Celem niniejszego artykułu nie jest omówienie aktualnego zwrotu etycznego $\mathrm{w}$ antropologii, lecz przedstawienie jednej z najnowszych teorii, która w ten nurt się wpisuje - tj. teorii moralności-jako-kooperacji (Curry 2007; Curry, Price, Price 2008; Curry, Chesters 2012; Curry 2016; Curry, Chesters, Van Lissa 2019a; Curry i in. 2019b; Curry, Mullins, Whitehouse 2019c). Jej główni autorzy - antropolodzy - dowodzą, że moralność wyewoluowała wraz z rozwojem ludzkich społeczności, aby promować kooperację, czego próbują dowieść także uczeni reprezentujący inne dyscypliny (np. Greene 2014; Haidt, Kesebir 2010; Rai, Fiske 2011; Sterelny, Fraser 2017; Tomasello, Vaish 2013). Psychologowie społeczni Jonhatan Haidt i Selin Kesebir zauważyli, że „[s]ystemy moralne to wzajemnie powiązane zbiory wartości, cnót, norm, praktyk, tożsamości, instytucji, technologii i rozwiniętych mechanizmów psychologicznych, które współpracują ze sobą, aby stłumić lub regulować egoizm i umożliwić wspólne życie społeczne" (2010, s. 800). Tage Rai (psycholog moralny) i Alan Fiske (antropolog) dodali, że „moralność istnieje, aby ułatwić tworzenie i utrzymywanie długoterminowych relacji społeczno-kooperacyjnych" (2011, s. 59). Natomiast Michael Tomasello (psycholog rozwojowy i wieloletni dyrektor Instytutu Antropologii Ewolucyjnej im. Maxa Plancka) i Amrisha Vaish (psycholog moralny) także utrzymują, że „,[m]oralność ludzka powstała ewolucyjnie jako zestaw umiejętności i motywów współpracy z innymi” (2013, s. 231). Podobnie wypowiada się Joshua Greene (psycholog eksperymentalny i neurobiolog), który twierdzi, że 
"[p]odstawową funkcją moralności jest promowanie i podtrzymywanie współpracy" (2015, s. 40), a w ślad za nim filozofowie - Kim Sterelny i Ben Frase podkreślają, że „fakty moralne to fakty dotyczące kooperacji oraz warunków i praktyk, które ją wspierają lub podważają" (2017, s. 981).

W odpowiedzi na różne formy współpracy, które ludzie wykorzystują w życiu codziennym, powstały różne zasady moralne, które tę współpracę i związane z nią problemy regulują (Curry 2016; Curry, Chesters, Van Lissa 2019a; Curry i in. 2019b; Curry, Mullins, Whitehouse 2019c). Takie ujęcie moralności w relacji do kooperacji dostarcza antropologii nowej, jednolitej koncepcji współtworzącej teorię moralności, której w antropologii brakuje. Dotychczasowe badania próbowały wyjaśnić moralność poprzez analizę wąskiego zestawu zachowań kooperacyjnych (zazwyczaj powiązanych $z$ altruizmem pokrewnym i altruizmem odwzajemnionym) i pomijały inne (np. koordynację czy rozwiązywanie konfliktów). Curry wraz ze współpracownikami - stosując teorię gier do analizy kooperacji - dokonali całościowej systematyzacji tego pojęcia i tym samym poszerzyli zakres badań nad moralnością (Curry 2016; Curry, Chesters, Van Lissa 2019a; Curry i in. 2019b; Curry, Mullins, Whitehouse 2019c).

Ponadto wcześniejsze prace empiryczne nie wyjaśniły, czy kooperacyjne ujęcie moralności występuje we wszystkich kulturach. Wobec braku uzgodnionej teorii moralności dotychczasowe prace nad międzykulturowymi różnicami w moralności (niespójne i niejednolite pod względem metodologicznym) nie mogły być przedmiotem porównań. Różne podejścia i miary stosowane przez badaczy uniemożliwiały stworzenie całościowego obrazu moralnego ludzi; niektórzy uczeni - mimo tych braków - uznawali ludzką moralność za uniwersalną (Brown 1991), inni - dokładnie odwrotnie - nawet zaprzeczali możliwości jej istnienia (Prinz 2007).

\section{W JAKI SPOSÓB KOOPERACJA WYJAŚNIA MORALNOŚĆ}

Ewolucjonizm w naukach przyrodniczych na długi czas zdeterminowało przekonanie o samolubności ludzkich zachowań moralnych, którego bronili spadkobiercy Charlesa Darwina, np. Piotr Kropotkin (de Waal 2014, s. 58). Kropotkin podkreślał siłę wzajemnej pomocy, dzięki której „odnotował współpracę między osobnikami tego samego gatunku" (de Waal 2014, s. 59). Koncepcja genetycznie uwarunkowanego altruizmu krewniaczego, czyli reguła biologa ewolucyjnego Williama Hamiltona (1964), potwierdziła wcześniejsze doniesienia antropologów i socjologów (np. Blau 1964; Gouldner 1992; Malinowski 1980) i otworzyła nowy rozdział badań nad kooperacją i moralnością w obrębie różnych dyscyplin, np. badania Roberta L. Triversa nad altruizmem odwzajemnionym (Trivers 1971), Martina A. Nowaka nad altruizmem pośrednim i sieciowym (np. Nowak 2006), Roberta Boyda i Petera Richersona nad koewolucją genetyczno-kulturową (np. Boyd, Richerson 2005), Tomasello nad źródłami ludzkiej kooperacyjności (np. Warneken, Tomasello 2009; Tomasello, Vaish 2013), Herberta Gintisa nad ewolucją własności prywatnej (np. Gintis 2007), modelowanie zachowań kooperatywnych za pomocą teorii gier (np. Axelrod, Hamilton 1981). 
Teoria gier bada za pomocą powtarzalnych eksperymentów, jakie strategie powinni wybrać gracze, żeby osiągnąć najlepsze wyniki. Działania podejmowane przez każdego z graczy mają wpływ na pozostałych uczestników gry (sytuacja współzależności społecznej). Gracze podejmują decyzję co do wyboru swoich strategii, biorąc te interakcje pod uwagę. W konsekwencji tej rywalizacji wyłoniony zostaje zwycięzca i przegrany, czyli zysk jednego jest stratą drugiego - w ten sposób działają tzw. gry o sumie zerowej (Axelrod 1984; Binmore 2017; Smith 1982). Natomiast może zdarzyć się także, że występują łączne zyski i straty stron interakcji (mniejsze bądź większe od zera) i wówczas mamy dwóch zwycięzców - mówimy wtedy o grze o sumie niezerowej. Te podstawowe założenia teorii gier stanowiły dla Curry’ego i jego współpracowników (Curry 2016; Curry, Chesters, Van Lissa 2019a; Curry, Mullins, Whitehouse 2019c) płaszczyznę do wyjaśnienia, jak dobór naturalny może faworyzować geny związane $\mathrm{z}$ kooperacją, to znaczy geny dla stabilnych ewolucyjnie strategii fenotypowych zaprojektowanych do osiągnięcia lepszej równowagi w interakcjach o sumie niezerowej. Należy tutaj wyraźnie podkreślić, iż istnieje wiele sposobów promowania genetycznego przetrwania i reprodukcji, ale tylko niektóre wykorzystują kooperację międzyludzką. Teoria moralności-jako-kooperacji stawia hipotezę, że tylko „strategie (nie)kooperacyjne są uważane za (nie)moralne” (Curry, Chesters, Van Lissa 2019a, s. 107).

Uznaje się, że koewolucja genetyczno-kulturowa, która wykorzystuje strategie kooperacyjne, spowodowała kilka ważnych przemian (np. Boyd, Richerson 2005; Henrich, Henrich 2007; Henrich, Muthukrishna 2021). Dobór naturalny również faworyzował geny związane $\mathrm{z}$ kooperacją między osobnikami $\mathrm{w}$ wielu różnych gatunkach, w tym u ludzi (np. Boyd, Richerson 2009; Nowak 2006; Tomasello 2016; West, Griffin, Gardner 2007). Ludzie wywodzą się z długiej linii naczelnych, które 50 milionów lat spędziły w grupach społecznych (np. Shultz, Opie, Atkinson 2011), a 2 miliony lat żyjąc jako intensywnie współpracujący łowcy-zbieracze (np. Tooby, DeVore 1987). W tym czasie wykształciły się u ludzi liczne biologiczne i psychologiczne adaptacje umożliwiające kooperację, rozumiane jako „próby” doboru naturalnego dążące do rozwiązywania - a przynajmniej niwelowania - problemów wynikających z kooperacji jednostek i grup (np. Boyd, Richerson 2005; Henrich, Henrich 2007; Henrich, Muthukrishna 2021).

Od niedawna kumulatywna ewolucja kulturowa (np. Boyd, Richerson, Henrich 2011; Pinker 2010; Tomasello 2016; Tomasello, Vaish 2013) pomaga ludziom wzmacniać kooperację - poprzez wynalezienie ewolucyjnie nowatorskich „narzędzi i reguł" (np. Binmore 2017; Hammerstein 2003; Nagel 1970; Tomasello 2016). Należy do nich zbiór innowacji kulturowych konstytuujących ludzką moralność, które zdaniem autorów teorii moralności-jako-kooperacji są jednocześnie rozwiązaniem problemów wywoływanych przez kooperację (Curry 2007, 2016; Curry, Chesters, Van Lissa 2019a; Curry, Mullins, Whitehouse 2019c). Nie jest to teoria ani pierwsza, ani jedyna. Teoria podstaw moralnych (ang. Moral Foundation Theory, MFT) zaproponowana przez Haidta i Jessego Grahama (2007) jeszcze przed teorią moralności jako kooperacji Curry’ego (2016), wykorzystuje Kwestionariusz Kodów Moralnych 
(ang. Moral Foundation Questionaire; Graham i in. 2011; Jarmakowski, Jarmakowska-Kostrzanowska 2016) do stworzenia pierwszej mapy moralności obejmującej pięć domen: Troska (vs. Krzywda), Sprawiedliwość (vs. Oszustwo), Lojalność (vs. Zdrada), Autorytet (vs. Kwestionowanie władzy) oraz Świętość (vs. Degradacja). Nie odnosi się jednak do teorii kooperacji (Haidt, Craig 2011). MAC powiększa mapę, dodając domeny związane z rodziną, wzajemnością, heroizmem czy własnością, ale nie obejmuje „troski” i „czystości”, które - według twórców - nie znajdują swoich odpowiedników w zidentyfikowanych typach kooperacji (Curry, Chesters, Van Lissa 2019a). Inny model oparty na Teorii Modeli Relacyjnej (ang. Relational Models Theory, RMT), zaproponowany przez Fiskego i Raia (Fiske, Rai 2014; Rai, Fiske 2011), obejmuje z kolei tylko cztery domeny moralne: jedność, hierarchię, równość i proporcjonalność. RMT nie odróżnia rodziny od grupy, wzajemności od nieuprzejmości ani nie dostrzega różnic między ,jastrzębimi” przejawami dominacji a „gołębimi” przejawami uległości (Curry, Chesters, Van Lissa 2019a). RMT - podobnie jak MAC - potwierdza, że „szkoda” lub „czystość” nie powinny być traktowane jako odrębne domeny. MFT, RMT, a także teoria moralności diadycznej (ang. Theory of Diadic Morality, TDM; Schein, Gray 2017) nie wyewoluowały jednak z podejścia opartego na kooperacji. Chociaż TDM argumentuje, że podstawą moralności jest minimalizowanie „szkód” i sugeruje różne formy ich naprawy (podobne do domen $\mathrm{MF}$ ), to jednocześnie uznaje naruszenia moralne za skutek działania mechanizmów psychologicznych zorientowanych na cel ogólny, a nie odrębny. W przeciwieństwie do MFT, TDM (podobnie jak RMT i MAC) wyklucza „czystość” jako odrębną domenę moralną, ale jednocześnie udowadnia, że jest ona formą „krzywdy” (Gray, Schein, Ward 2014). Podobnie jak w przypadku MAC, teoria moralności oparta na „braniu (czyjejś) strony" (ang. Side-Taking Theory of Morality, STTM), zaproponowana przez Petera DeScioliego i Roberta Kurzbana (2009), zakłada kooperację z jedną ze stron. Przyjmuje, że osąd moralny jest strategią wyboru strony w konflikcie w celu uniknięcia kosztów związanych z konfliktem, przy czym nie wyklucza się wspierania innych stron w różnych walkach, nawet jeśli w ten sposób dochodzi do skrzywdzenia jednej z tych, z którymi uprzednio się współpracowało (DeScioli 2016; DeScioli, Kurzban 2009). MAC natomiast pozwala na usprawiedliwianie zachowań moralnych, takich jak wzmacnianie lub sabotowanie własnej reputacji wśród rodziny i przyjaciół (Barclay 2016), dobór partnerów do kooperacji (Krasnow i in. 2016) czy budowanie sojuszy społecznych dla ochrony swoich zasobów (Petersen 2013).

Teoria moralności-jako-kooperacji dowodzi, że moralność to zbiór biologicznych i kulturowych rozwiązań odpowiadających powtarzającym się w życiu społecznym problemom współpracy (Curry 2016; Curry, Chesters, Van Lissa 2019a). Jej fundamentalnych założeń należy szukać w biologii ewolucyjnej i teorii gier, które wskazują na całe spektrum problemów wynikających z kooperacji, a którym jednocześnie przypisuje się różne funkcjonalne czy być może też odrębne rozwiązania fenotypowe (np. Lehmann, Keller 2006; Sachs i in. 2004). Curry ze współpracownikami (Curry 2016; Curry, Chesters, Van Lissa 2019a; Curry, Mullins, Whitehouse 2019c) podsumował te problemy i uporządkował je w siedem kategorii: (1) przydział zasobów 
Tabela 1. Relacje między zachowaniami kooperacyjnymi a typami moralności

\begin{tabular}{|c|l|l|l|l|l|}
\hline $\begin{array}{c}\text { Domena } \\
\text { moralna }\end{array}$ & Problem & $\begin{array}{l}\text { Rozwiązanie } \\
\text { zorientowane } \\
\text { na kooperacje }\end{array}$ & \multicolumn{2}{|c|}{ Cnoty moralne } & Wady moralne \\
\hline 1 & Rodzina & $\begin{array}{l}\text { Dobór } \\
\text { krewniaczy }\end{array}$ & $\begin{array}{l}\text { Altruizm } \\
\text { krewniaczy }\end{array}$ & $\begin{array}{l}\text { Obowiązek opieki, } \\
\text { szczególne obowiązki } \\
\text { wobec krewnych }\end{array}$ & $\begin{array}{l}\text { Kazirodztwo, } \\
\text { zaniedbanie }\end{array}$ \\
\hline 2 & Grupa & Koordynacja & Mutualizm & $\begin{array}{l}\text { Lojalność, jedność, } \\
\text { solidarność, } \\
\text { konformizm }\end{array}$ & $\begin{array}{l}\text { Zdrada, } \\
\text { zaprzedanie }\end{array}$ \\
\hline 3 & Wzajemnośćc & $\begin{array}{l}\text { Dylemat } \\
\text { społeczny }\end{array}$ & $\begin{array}{l}\text { Altruizm } \\
\text { odwzajemniony }\end{array}$ & $\begin{array}{l}\text { Wzajemność, } \\
\text { wiarygodność, } \\
\text { przebaczenie }\end{array}$ & $\begin{array}{l}\text { Oszukiwanie, } \\
\text { niewdzięczność }\end{array}$ \\
\hline 5 & Sohaterstwo & $\begin{array}{l}\text { Rozwiązywanie } \\
\text { konfliktów } \\
\text { (rywalizacja) }\end{array}$ & $\begin{array}{l}\text { „astrzębie” } \\
\text { przejawy } \\
\text { dominacji }\end{array}$ & $\begin{array}{l}\text { Odwaga, } \\
\text { hart ducha, } \\
\text { hojność }\end{array}$ & $\begin{array}{l}\text { Tchórzostwo, } \\
\text { skąstwo }\end{array}$ \\
\hline 7 & $\begin{array}{l}\text { Rozwiązywanie } \\
\text { konfliktów } \\
\text { (rywalizacja) }\end{array}$ & $\begin{array}{l}\text { „Gołębie” } \\
\text { przejawy } \\
\text { uległości }\end{array}$ & $\begin{array}{l}\text { Szacunek, } \\
\text { posłuszeństwo, } \\
\text { pokora }\end{array}$ & $\begin{array}{l}\text { Brak szacunku, } \\
\text { pycha }\end{array}$ \\
\hline 6 & Uczciwość & $\begin{array}{l}\text { Rozwiązywanie } \\
\text { konfliktów } \\
\text { (negocjacje) }\end{array}$ & $\begin{array}{l}\text { Podział } \\
\text { spornych } \\
\text { zasobów }\end{array}$ & $\begin{array}{l}\text { Uczciwość, } \\
\text { bezstronność, } \\
\text { równość }\end{array}$ & $\begin{array}{l}\text { Niesprawiedliwość, } \\
\text { faworyzowanie }\end{array}$ \\
\hline $\begin{array}{l}\text { Rozwiązywanie } \\
\text { konfliktów } \\
\text { (posiadanie) }\end{array}$ & Własność & $\begin{array}{l}\text { Poszanowanie } \\
\text { własności, } \\
\text { prawa własnośc }\end{array}$ & $\begin{array}{l}\text { Kradzież, } \\
\text { wykroczenie }\end{array}$ \\
\hline
\end{tabular}

Opracowanie własne na podstawie: Curry, Chesters, Van Lissa 2019c, s. 108.

krewnym (Hamilton 1964); (2) koordynacja przynosząca obopólne korzyści (Lewis 1969); (3) wymiana społeczna (Trivers 1971); oraz rozwiązywanie konfliktów poprzez rywalizację obejmujące (4) ,jastrzębie” przejawy dominacji i (5) „gołębie” przejawy uległości (Smith, Price 1973); (6) podział spornych zasobów (Skyrms 1996); oraz (7) uznanie czyjejś własności (Gintis 2007). Tabela 1 przedstawia ich systematyzację wraz z krótką próbą objaśnienia przypisanych im cnót i wad moralnych.

Poniżej dokonano przeglądu każdego z problemów oraz wyjaśniono relacje pomiędzy poszczególnymi kategoriami kooperacji a odpowiednim typem moralności, jaki się z nim wiąże.

\section{PRZYDZIAŁ ZASOBÓW KREWNYM (RODZINA)}

Koncepcja silnej wzajemności (ang. strong reciprocity) - jako formy altruizmu będącej cechą wybitnie ludzką - służy do wyjaśnienia kooperacji jako zachowania społecznego. Herbert Gintis wskazał, że człowiek jest „predystynowany do kooperacji z innymi i karania niekooperujących" (Gintis 2000, s. 169). Następnie wspólnie 
z Samuelem Bowlesem przedstawili silną wzajemność w postaci (symulacyjnego) modelu kooperacji i kar (ang. model of cooperation and punishment), w którym udowadniają, że „członkowie grupy korzystają ze wzajemnego przestrzegania norm społecznych, silne jednostki stosują się do normy i karzą łamiących normy, nawet jeśli w rezultacie otrzymują niższą "wypłatę» (ang. payoffs) niż pozostali członkowie grupy, tacy jak samolubni agenci, którzy naruszają normę i nie karzą, oraz zwykli kooperanci, którzy przestrzegają normy, ale nigdy nie karzą tych, którzy ją naruszyli" (Bowles, Gintis 2004, s. 17). Podobnie uważają inni uczeni, np. Boyd i Richerson (2005), Ernst Fehr i Urs Fischbacher (2004), Fehr i Simon Gächter (2002), Fehr i Klaus Shmidt (1999), Natalie Henrich i Joseph Henrich (2007), Joseph Henrich i Michael Muthukrishna (2021), widząc w ludzkiej zdolności do ustanawiania i egzekwowania norm społecznych cechę decydującą o wyjątkowości ludzkiej kooperacji $\mathrm{w}$ świecie istot żywych.

Teoria moralności-jako-kooperacji zakłada, że strategie altruizmu krewniaczego są uznawane za moralnie dobre, ponieważ przynoszą korzyści obu stronom (Curry 2016; Curry, Mullins, Whitehouse 2019c). Na podstawie tego założenia próbuje wyjaśniać takie zjawiska, jak np. opiekowanie się potomstwem (Edel 1962) czy pomaganie członkom rodziny (Fukuyama 1997; Wong 1984) i unikanie chowu wsobnego (Lieberman, Tooby, Cosmides 2003), które są powszechnie akceptowane jako ważne elementy moralności.

\section{KOORDYNACJA PRZYNOSZACA OBOPÓLNE KORZYŚCI (GRUPA)}

W teorii gier analizowane są sposoby podejmowania optymalnych decyzji w zależności od sytuacji. Badaniom poddawane są strategie, jakie gracze powinni wybrać, żeby osiągnąć jak najlepsze wyniki (Lewis 1969) - inaczej: poszukiwane są rozwiązania problemu koordynacji działań obu graczy na rzecz osiągnięcia zamierzonych celów. Ludzie, podobnie jak zwierzęta, używają różnych strategii (np. dzielenie się zdobyczami, przywództwo, sygnalizacja, odznaki przynależności do grupy, mózg społeczny), aby rozwiązać te problemy (np. Alvard 2001; Curry, Chesters 2012; McElreath, Boyd, Richerson 2003), i tworzą stabilne koalicje i sojusze (np. Balliet, Wu Junhui, De Dreu 2014; Blau 1992; Emerson 1982; Harcourt, de Waal 1992; Homans 1975a, 1975b, 1992).

Teoria gier symuluje warunki związane z potrzebą skoordynowania działań (Nash 1950; von Neumann, Morgenstern 1944), z którymi ludzie są konfrontowani w życiu codziennym, a które zostały opisane przez antropologów, filozofów, psychologów, socjologów czy biologów (np. Argyle 1991; Dunbar 2016; Matsuzawa 2001; Piaget 1967; Tomasello 2016). Kultura rozumiana jako „proces koordynacji społecznej” (Tomasello 2015, s. 10), w której ramach następuje „podejmowa[nie] przez jednostki prób współpracy i komunikowania się z innymi (prób wspólnej pracy czy kooperacji)" (Tomasello 2015, s. 19), sprawia, że „życie w grupie zaczęło przekształcać się w jedno wielkie działanie kooperatywne, zmierzające do utworzenia znacznie większego wspólnego świata - kultury. [...] [Z]orientowanie na grupę było oparte na nowej 
umiejętności: tworzeniu wspólnego gruntu kulturowego poprzez znane wszystkim konwencje kulturowe, normy i instytucje” (Tomasello 2015, s. 20-21). „Konwencjonalizacja” postępowania z elementami „koordynacyjnymi” i „transmisyjnymi” wytworzyła „praktyki kulturowe, w ramach których jednostki de facto koordynują działania z całą grupą kulturową za pośrednictwem znanych kolektywnie konwencji, norm i instytucji kulturowych" (Tomasello 2015, s. 143). Aby jednak stało się to możliwe, niezbędne jest - w ocenie Tomasello - „wspólne lub grupowe podejmowanie decyzji, które było regularnym elementem działań kooperatywnych" (Tomasello 2015, s. 193).

Teoria moralności-jako-kooperacji zakłada, że rozwiązywanie problemów związanych z koordynacją jest moralnie dobre, ponieważ/kiedy przynosi obopólne korzyści. Próbuje w ten sposób wyjaśnić, dlaczego udział we wspólnych przedsięwzięciach (Tomasello 2016), faworyzowanie własnej grupy (Bernhard, Fischbacher, Fehr 2006; Gert 2013; Tomasello 2016) i przyjmowanie lokalnych konwencji (Gibbard 1990b) są powszechnie akceptowane jako ważne elementy moralności.

\section{WYMIANA SPOŁECZNA (WZAJEMNOŚĆ)}

W teorii gier podejmowane są różne dylematy społeczne, np. dylemat więźnia (ang. The Prisonners Dilemma) i problem zaufania (Nash 1950); gra w cykora (ang. Chicken Game albo ang. Hawk-Dove Game) (Sugden 1986) i problem koordynacji, własności i posiadania; gra w polowanie na jelenia (ang. Stag Hunt Game) o zapewnienie bezpieczeństwa i rozwiązanie problemu koordynacji (Skyrms 2001); tragedia wspólnego pastwiska (ang. Tragedy of the Commons) (Hardin 1968) i problem ograniczoności zasobów (Ostrom 1990, 2003, 2013). We wszystkich tych przypadkach pomyślne wyniki kooperacji są zagrożone działaniami jednostek, które kierując się egoistycznymi interesami, często sprzecznymi z interesami grupy, mają tendencję do „jazdy na gapę” (ang. free riders), czyli korzystają z wysiłków innych podejmowanych w zbiorowej praktyce (Olson 2012, s. 40-41, 53). Problem ten może być rozwiązany za pomocą warunkowej kooperacji lub altruizmu odwzajemnionego, z zastosowaniem np. strategii „wet za wet” (ang. tit-for-tat; Axelrod 1984; Trivers 1971). Dowiedziono, że warunkowa kooperacja często występuje w życiu wielu gatunków zwierząt (np. Carter 2014; Santema, Schlicht, Kempenaers 2019), w tym także wśród ludzi (np. Cosmides, Tooby 1992, 2005; Henrich i in. 2005).

Warto w tym miejscu zauważyć, że Tomasello (2016) podkreśla przewodnią rolę mutualizmu względem altruizmu, w którym tak wielu uczonych widzi źródło kooperacji. Mutualizm, który u Tomasella „polega na tym, że wszyscy odnosimy korzyści z naszej kooperacji, ale tylko wtedy, gdy pracujemy wspólnie, co możemy nazwać bezpośrednią współpracą (ang. collaboration)" (Tomasello 2016, s. 72), wydaje się w ten sposób odnosić do współzależności społecznej, propagowanej przez psychologów społecznych zajmujących się teorią gier. Takie rozumowanie uzasadnia zaproponowaną przez Briana Skyrmsa $(1996,2001)$ strategię - warunkową kooperację, która jest sytuacją typu win-win. Także wielu socjologów, np. Richard Sennet (2012), wskazuje 
na sytuacje równowagi, w których przy idealnej kooperacji wszyscy wygrywają. Co więcej, Tomasello twierdzi, że mutualizm może stanowić źródło altruizmu, w tym znaczeniu, że tworzy warunki sprzyjające rozwojowi ludzkich zachowań zorientowanych altruistycznie (2016). Znaczenie mutualizmu w podobnym kontekście rozważane było już wcześniej przez innych uczonych na polu badań socjobiologicznych, np. Redouana Bshary'ego i Alexandra Grutterę (2006) czy Tima Cluttona-Brocka (2002). Natomiast Andy Gardner, Ashleigh Griffin i Stuart West (2007) skrytykowali używanie terminu mutualizm w odniesieniu do kooperacji, ograniczając się do używania pojęcia obopólnych korzyści.

Teoria moralności-jako-kooperacji zakłada, że kiedy rozwiązania dylematów społecznych przynoszą obopólne korzyści, są one uważane za moralnie dobre. Próbuje w ten sposób wyjaśnić, dlaczego wzajemność (za Curry 2016: Chilton, Neusner 2009) oraz jej składowe, tj. zaufanie (za Curry 2016: Baier 1995), cierpliwość (za Curry 2016: Curry, Price, Price 2008), wdzięczność (za Curry 2016: Emmons, McCullough 2004), poczucie winy (za Curry 2016: Gibbard 1990b), przeprosiny (za Curry 2016: Ohtsubo, Watanabe 2009) i przebaczenie (za Curry 2016: Downie 1965; Godfray 1992; Richards 1988) są powszechnie wymieniane jako ważne elementy moralności.

\section{ROZWIĄZYWANIE KONFLIKTÓW POPRZEZ RYWALIZACJĘ („JASTRZĘBIE” PRZEJAWY DOMINACJI I „GOŁĘBIE” PRZEJAWY ULEGŁOŚCI)}

Tragedia wspólnego pastwiska (ang. Tragedy of the Commons) i problem ograniczoności zasobów (Hardin 1968), w tym konflikty o dostęp do żywności, terytorium czy partnerów (Huntingford, Turner 2013), stwarzają okazje do kooperacji (np. Ostrom 1990, 2013), aby uniknąć ewentualnej kosztownej przegranej (np. Smith, Price 1973). Teoria gier wskazuje na rozwiązania oparte na rywalizacji, w których jednostki wykazują swoją „zdolność bojową” i słabszy zawodnik ustępuje silniejszemu (np. Gintis, Smith, Bowles 2001; Smith, Price 1973). Robert Axelrod wymienia inne także często stosowane - cztery zasady: (1) unikania konfliktu przez oferowanie przeciwnikowi współpracy (celem jest nadal pomnażanie zysku, a nie altruistyczna postawa); (2) stosowania odwetu, gdy jedna ze stron zostaje oszukana; (3) wybaczania, czyli podejmowania współpracy, jeśli zostanie ona zaproponowana po uprzednich oszustwach drugiej strony; (4) stosowania zrozumiałej dla drugiej strony metody postępowania, co da jej szansę na modyfikowanie swojego zachowania, aby rozpocząć współpracę (Axelrod 1984, s. 109-123). Susan Riechert (1998), a później także Ian Hardy i Mark Briffa (2013) wskazali, że rywalizacje o takim charakterze powszechnie występują w naturze i często decydują o hierarchii dominacji, tj. przydzielaniu zasobów według rangi. Ludzie wykazują się podobnymi zachowaniami związanymi ze statusem (np. Mazur 2005; Sell, Tooby, Cosmides 2009) i kulturowo rozwiniętymi hierarchiami (np. Boone 1992; Rubin 2000).

Teoria moralności-jako-kooperacji zakłada, że „jastrzębie” przejawy dominacji i „gołębie” przejawy uległości są uważane za moralnie dobre, jeśli przynoszą obopólne 
korzyści. Wychodząc z tego założenia, próbuje wyjaśnić, dlaczego męstwo, odwaga, zdolności i dowcip versus pokora, atencja, posłuszeństwo i szacunek są powszechnie wymieniane jako ważne składniki moralności (Curry 2007).

\section{PODZIAŁ SPORNYCH ZASOBÓW (WŁASNOŚĆ)}

Kiedy pożądany przez obie strony zasób jest podzielny, możliwe jest takie skoordynowanie działań przez graczy, że zostanie osiągnięta równowaga Nasha, tj. sytuacja, w której jeden z graczy dokonuje rewizji swojej strategii, a pozostali gracze, nie zmieniając swoich strategii, nie pozwalają wygrać temu, który dokonał zmiany (Nash 1950). Aby to osiągnąć, Skyrms wskazuje na trzy możliwe strategie: (1) kiedy jeden i drugi gracz współpracują; (2) kiedy jeden i drugi gracz oszukują; (3) kiedy gracze dzielą zasoby, unikając strat wynikających z ewentualnego konfliktu (1996). Badacz doszedł także do wniosku, że zarówno nauki biologiczne, jak i polityczne błędnie zakładają, że kooperanci spotykają głównie kooperantów, a oszuści oszustów - kooperanci i oszuści spotykają się ciągle, ale to kooperanci radzą sobie lepiej i co więcej, efektem tych spotkań nie zawsze będzie współpraca (Skyrms 2001). Trzecim rozwiązaniem może być podzielenie zasobu proporcjonalnie do względnej (przetargowej) siły stron konfliktu (Skyrms 1996). Dotyczy to przede wszystkim mniej więcej równych sobie jednostek i skutkuje równymi udziałami (Smith 1982). W praktyce założenia te przekładają się na stosowane przez ludzi takich strategii, jak „tnę, ty wybierasz”, „spotykamy się pośrodku”, „dziel różnicę” czy wygrywanie „na zmianę”, które są rozpowszechnionymi sposobami rozwiązywania sporów (za Curry 2016: Brams, Taylor 1996).

Teoria moralności-jako-kooperacji zakłada, że kiedy podział zasobów pozwala uniknąć kosztownej walki, a zatem realizuje obopólną korzyść, jest uważany za moralnie dobry. Próbuje w ten sposób wyjaśnić, dlaczego uczciwość (Rawls 1958) i gotowość do kompromisu (za Curry 2016: Pennock, Chapman 1979) są powszechnie wymieniane jako ważne składniki moralności.

\section{UZNANIE WŁASNOŚCI PRYWATNEJ (POSIADANIE)}

W teorii gier udowodniono także, że spory dotyczące zasobów można rozwiązać poprzez uznanie pierwotnej własności (Gintis 2007; Smith 1982). Liczne badania pokazują, że takie działanie w sytuacjach konfliktowych jest powszechnie stosowane w naturze (np. Sherratt, Mesterton-Gibbons 2015; Strassmann, Queller 2014). Psychologiczne i socjologiczne eksperymenty wykorzystujące winiety potwierdzają, że również ludzie potrafią zrezygnować z roszczeń, szanując pierwszeństwo pierwotnej własności (DeScioli, Karpoff 2015). Do tych samych wniosków prowadzą wyniki gier eksperymentalnych (Kahneman, Tversky 2013) czy badania w obszarze prawa (Rose 1985) i stosunków międzynarodowych (Johnson, Duffy 2014). Poszanowanie własności prywatnej, w takiej czy innej formie, wydaje się uniwersalizmem niezależnym od kultury (Herskovits 2018). 
Teoria moralności-jako-kooperacji zakłada, że uznanie pierwotnej własności pozwala uniknąć kosztownej walki, a zatem prowadzi do obopólnych korzyści, przez co jest uważane za moralnie dobre. Próbuje w ten sposób wyjaśnić, dlaczego szacunek dla własności i zakaz kradzieży (Becker 1977; Pennock, Chapman 1979) są powszechnie wymieniane jako ważne elementy moralności.

\section{CO JEST ISTOTĄ MORALNOŚCI?}

Analiza etnograficzna, którą przeprowadzili Oliver Curry, Daniel Mullins i Harvey Whitehouse (2019c), wykorzystując dane dostępne w archiwach Human Relations Area Files, opisuje 60 społeczeństw reprezentujących sześć regionów świata, tj. Afrykę Subsaharyjską, region Morza Śródziemnego, Wschodnią Euroazję, Wyspy Pacyfiku, Amerykę Północną, Amerykę Południową. Uczeni dokonali 962 obserwacji zachowań kooperacyjnych o pozytywnej wartości moralnej. W jednym zaledwie przypadku, wśród ludu Chuuk zamieszkującego Mikronezję, nie występuje poszanowanie dla własności prywatnej. Okradanie innych u Chuuków świadczy o ,jastrzębim” przejawie dominacji, która jest wysoko ceniona przez członków ich społeczności. W rejonie Amhara w Etiopii dbanie o rodzinne obowiązki stanowi o wartości moralnej, a zaniedbywanie rodziny uznawane jest za naganne postępowanie. W Korei natomiast bardzo ważne jest utrzymywanie jak najlepszych relacji z sąsiadami i wysokiego poziomu solidarności wewnątrz grup. Ludy Kapakuz indonezyjskiej prowincji Papua respektują zasadę nazywaną uta-uta (pol. „pół-pół”), która oznacza dokonanie sprawiedliwego podziału. Wśród ludu Tarahumara z meksykańskiego stanu Chihuahua szacunek dla własności prywatnej reguluje wszelkie relacje społeczne.

W żadnym $\mathrm{z}$ badanych przez Curry’ego i jego zespół społeczeństw wytypowane zachowania kooperacyjne nie wykazały negatywnej wartości moralnej. Ich wnioski potwierdziły przyjęte przez Curry’ego (2007) założenia, że ludzie w różnych kulturach są konfrontowani z podobnymi problemami społecznymi wynikającymi z kooperacji i używają podobnych rozwiązań (zasad moralnych), aby sobie z nimi radzić na co dzień. Różnica pomiędzy poszczególnymi kulturami polega na wadze, jaką różne kultury nadają poszczególnym regułom - różne zasady moralne mają różną wartość (Curry, Chesters, Van Lissa 2019a; Curry, Mullins, Whitehouse 2019c).

Należy podkreślić, że dotąd prowadzone badania w zakresie ludzkiej moralności jak już wspomniano - były ograniczone do wybranych kwestii, np. altruizmu krewniaczego w przypadku World Value Survey (Inglehart, Baker 2000; Inglehart, Norris 2009) czy troszczenia się o krewnych (Wojciszke, Baryła 2000), pomagania członkom swojej grupy (Graham i in. 2011; Schwartz 1992), wzajemności (Eisenberger i in. 2004; Park, Peterson, Seligman 2006; Schwartz 1992), „jastrzębich” przejawów dominacji (Cross i in. 2014), autorytetu (Graham i in. 2011) i szacunku do przełożonych (Schwartz 1992), dzielenia spornych zasobów (Davey i in. 1999) oraz poszanowania czyjejś własności (Weeden, Kurzban 2013). Wymienione badania nie podejmowały jednak próby analizy moralnego znaczenia przez pryzmat zachowań kooperatywnych. 
Mierzyły też różne aspekty moralności na różne sposoby, korzystając z rozmaitych skal pomiaru i prób najczęściej ograniczonych do uczniów bądź studentów. Dlatego utrudnione jest ich porównanie i wyprowadzenie wspólnych wniosków.

\section{PODSUMOWANIE}

Antropologia próbująca wyjaśniać skomplikowane zagadnienie moralności zaczęła interesować się nowymi obszarami, jak i nowymi metodami, które mają szansę ją przybliżyć do wyczekiwanej spójnej teorii moralności. Pojawiają się nowe kierunki badań nad pielęgnowaniem wartości etycznych, które są podejmowane w perspektywie religijnej (np. Cassaniti 2015; Cook 2010; Lester 2005) czy z perspektywy rodzicielstwa (np. Paxson 2004; Kuan 2015) bądź aktywizmu (np. Dave 2012; Heywood 2015; Lazar 2016). Pojawia się także zainteresowanie wartościami, czym zajmują się np. Curry, Matthew Chesters i Caspar Van Lissa (2019a), David Graeber (2018) czy Joel Robbins (2012). Badanie specyfiki reguł, rozumianych jako sposób organizowania życia etycznego, pozwala dojrzeć nie tylko kiedy i gdzie dana reguła występuje, ale też, że staje się interesująca sama w sobie (Dresch, Scheele 2015; Clarke 2015). Powtarzając za Laidlawem (2013), nie tyle wyłania się nowa subdyscyplina, ile dostrzec można odnowienie bądź ponowne odkrywanie nazwanych już pojęć, głęboko zakorzenionych $\mathrm{w}$ antropologii, ale wymagających ponownego przemyślenia - zwłaszcza w kontekście ludzkiej sprawczości i przyczynowości społecznej. Przykładem ilustrującym te tendencje niech będzie kwestia „czynienia dobra” i sposób jej organizacji we współczesnym świecie. Podejmowana jest przecież w kontekście zarówno praw człowieka, jak i humanitaryzmu (np. Bornstein 2012; Englund 2006; Laidlaw 2013; Fassin 2012). Inną niezwykle aktualną tematyką są zjawiska dystansu i ich praktykowanie (Yarrow i in. 2015; Manderson, Levine 2020). Wreszcie należy zwrócić uwagę na coraz częstsze korzystanie $\mathrm{z}$ prac antropologicznych $\mathrm{w}$ innych dziedzinach, jak np. w psychologii (Haidt 2012; Tomasello 2016), filozofii moralnej (Lear 2015; Lillehammer 2014), teologii (Banner 2014) czy ekonomii (Taleb 2001; Taylor 2013).

Teoria moralności-jako-kooperacji wpisuje się w nurt nowej konceptualizacji znanych problemów. Ludzie w różnych kulturach są konfrontowani z podobnymi problemami społecznymi i używają podobnych zbiorów zasad moralnych, którymi posługują się w codziennym życiu. Curry twierdzi, że w odpowiedzi na siedem form kooperacji, które są wykorzystywane przez ludzi w relacjach z innymi, wyewoluowały różne zasady moralne. Moralność rozwijała się wraz z rozwojem ludzkich społeczności, aby promować kooperację wśród ich członków. W ten sposób rozumiana moralność wprost wpisuje się w dobrze znane koncepcje Durkheima. Poprzestając na tym, teoria MAC nie wniosłaby nic nowego do starych problemów. Curry próbuje jednak wyjaśnić, że ludzie nie tylko przestrzegają analogicznych zasad moralnych niezależnie od kultury, ale także stara się wyeksplikować, że różnią się między sobą, nadając różne znaczenia tym zasadom. Troska o rodzinę, która obligatoryjnie wiąże się z kooperacją z najbliższymi na rzecz jej wspólnego dobra, stanowi bezdyskusyjnie wartość moralną we wszystkich kulturach. Podobnie rzecz ma się z niespokrewnionymi 
grupami, w których ludzie nawiązują i utrzymują relacje oparte na solidarności i lojalności. Szerzej rozumiana wymiana społeczna wymaga od nas zaufania do innych i odwzajemniania otrzymanej już pomocy - w zależności od okoliczności może w różnych kulturach wzbudzać poczucie winy, wdzięczność czy przymuszać do wybaczania bądź naprawiania wyrządzonego zła. Męstwo, odwaga i hojność, a także szacunek dla osób stojących wyżej w hierarchii, sprawiedliwy podział dóbr i szacunek dla własności - stosowane są do rozwiązywania konfliktów społecznych. Te zasady moralne mają charakter uniwersalny, choć są zróżnicowane międzykulturowo w taki sposób, iż różne kultury akcentują różne cnoty i piętnują inne wady.

Większość tych pojęć została już obszernie udokumentowana w opisach antropologicznych, a nauki przyrodnicze czy neurokognitywne próbują podejmować się ich wyjaśnienia w obrębie swoich dyscyplin. To, co nowe u Curry’ego, to zebranie tych pojęć $\mathrm{w}$ jeden kodeks aspirujący do uniwersalnego zbioru wartości charakterystycznych dla ogółu ludzi. Ambitne podejście Curry’ego jest próbą połączenia podejść badawczych charakterystycznych dla różnych dyscyplin. W tym przypadku, odwrotnie do panującego trendu, antropolodzy jako autorzy teorii moralności-jako-kooperacji dokonali analizy wyników z symulacji zachowań kooperatywnych $\mathrm{z}$ wykorzystaniem teorii gier stosowanej w ekonomii, socjobiologii czy socjologii. Posłużyły im one do ustalenia katalogu powtarzających się zachowań kooperatywnych u ludzi i związanych z nimi problemów. Następnie, analizując rozwiązania tychże problemów - stosowane przez różne społeczności - ustalili wartości moralne im przypisywane. Skatalogowanie problemów wynikających z kooperacji i wartości nadawanych poszczególnym typom rozwiązań stanowi ważne podsumowanie badań $\mathrm{z}$ wielu dyscyplin. Trzeba jednak $\mathrm{z}$ całą mocą podkreślić, iż weryfikacja poprawności tego katalogu, która opiera się wyłącznie na danych udostępnionych w bazach Human Relations Area Files, nie dostarcza wyczerpujących dowodów. Pożądanym uwiarygodnieniem powinno być skonfrontowanie teorii moralności-jako-współpracy w kulturowej rzeczywistości z zastosowaniem metod etnograficznych.

Uznanie faktu, że ludzie posługują się wspólnym kodeksem moralnym, sprawia, że odwieczna debata między moralnymi relatywistami i uniwersalistami wchodzi w nową fazę i wymaga weryfikacji dotychczasowych stanowisk i argumentów. Taka rewizja, na podstawie MAC, może i powinna dotyczyć także innych dziedzin, które czerpią $\mathrm{z}$ antropologii nie tylko inspirację, ale przede wszystkim wiedzę umożliwiającą im redefinicję wielu podejść, jak stało się w przypadku np. nauk o środowisku (Curry i in. 2019b) czy przedsiębiorczości humanistycznej (Landowska, Della Piana, Feola 2020). Trzeba jednocześnie mieć na uwadze, że wciąż powstają nowe szkoły myślenia, a debata w obrębie antropologii moralności trwa - urzeczywistniając nowy zwrot.

\section{LITERATURA}

A lva rd Mi ch a el 2001, Mutualistic Hunting, [w:] C.B. Stanford, H.T. Bunn (red.), Meat-eating and Human Evolution, Oxford University Press, New York, s. 261-278.

A rgyle Mich a el 1991, Cooperation (Psychology Revivals): The Basis of Sociability, Routledge, New York. 
A xelrod Robert M. 1984, The Evolution of Cooperation, Basic Books, New York.

Axelrod Robert, Hamilton William D. 1981). The Evolution of Cooperation. Science, vol. 211, nr 4489, s. 1390-1396.

B a i e r A n nette 1995, Moral Prejudices: Essays on Ethics, Harvard University Press, Cambridge, Massachusetts - London.

Balliet Daniel, Wu Junhui, De Dre u Carsten 2014, Ingroup Favoritism in Cooperation: A Meta-analysis, Psychological Bulletin, vol. 140, nr 6, s. 1556-1581.

B a n n e r M i ch a el 2014, The Ethics of Everyday Life: Moral Theology, Social Anthropology, and the Imagination of the Human, Oxford University Press, Oxford.

B a r c l a y P at 2016, Biological Markets and the Effects of Partner Choice on Cooperation and Friendship, Evolutionary Psychology, vol. 7, s. 33-38.

B e cker L a w r e n e C. 1977, Property Rights: Philosophic Foundations, Routledge, London.

B e n e d i ct R u th 2011, Wzory kultury, tłum. J. Prokopiuk, Wydawnictwo Muza SA, Warszawa.

B ernhard Helen, Fis chbacher Urs, Fehr Ernst 2006, Parochial Altruism in Humans, Nature, vol. 442, nr 7105, s. 912-915.

B in more Kenneth 2017, Teoria gier, tłum. I. Konarzewska, Wydawnictwo Uniwersytetu Łódzkiego, Łódź.

B l a u P e t e r M. 1964, Exchange and Power in Social Life, John Wiley \& Sons, New York.

Blau Peter 1992, Sprawiedliwość w wymianie społecznej, [w:] M. Kempny, J. Szmatka (red.), Współczesne teorie wymiany. Zbiór tekstów, PWN, Warszawa, s. 243-258.

B o o n e James L. 1992, Competition, Conflict, and the Development of Social Hierarchies, [w:] E.A. Smith, B. Winterhalde (red.), Evolutionary Ecology and Human Behavior, Aldine de Gruyter, New York, s. 301-337.

B ornste in Eric a 2012, Disquieting Gifts: Humanitarianism in New Delhi, Stanford University Press, Stanford.

B ow les S a muel, G in t is He r b e r t 2004, The Evolution of Strong Reciprocity: Cooperation in Heterogeneous Populations, Theoretical Population Biology, vol. 65, nr 1, s. 17-28.

B oyd Robert, Richers on Peter 2005, The Origin and the Evolution of Culture, Oxford University Press, Oxford.

B oyd Robert, Richers on Peter 2009, Culture and the Evolution of Human Cooperation, Philosophical Transactions of the Royal Society B: Biological Sciences, vol. 364, $\mathrm{nr}$ 1533, s. 3281-3288.

B oyd Robert, Richerson Peter, Henrich Joseph 2011, The Cultural Niche: Why Social Learning is Essential for Human Adaptation, Proceedings of the National Academy of Sciences, vol. 108, Supplement 2, s. 10918-10925.

B rams Steven, Taylor Al a n 1996, Fair Division: from Cake-Cutting to Dispute Resolution, Cambridge University Press, Cambridge.

B r ow n D on ald E. 1991, Human Universals, McGraw-Hill, New York.

B shary Red ou a n, Grutter A lex and r a 2006, Image Scoring and Cooperation in a Cleaner Fish Mutualism, Nature, vol. 441, nr 7096, s. 975-978.

C a r t e r G e rald 2014, The Reciprocity Controversy, Animal Behavior and Cognition, vol. 1, nr 3, s. 368-386.

C a s s a n it i J u li a 2015, Living Buddhism: Mind, Self and Emotion in a Thai Community, Cornell University Press, Ithaca-New York.

Cassaniti Julia, Hickman Jacob 2014, New Directions in the Anthropology of Morality, Anthropological Theory, vol. 14, nr 3, s. 251-262.

Clarke Morgan 2015, Legalism and the Care of the Self: Shariah Discourse in Contemporary Lebanon, [w:] P. Dresch, J. Scheele (red.), Legalism: Rules and Categories, Oxford University Press, Oxford, s. 231-258.

Clutton-Brock Tim 2002, Breeding Together: Kin Selection and Mutualism in Cooperative Vertebrates, Science, vol. 296, nr 5565, s. 69-72.

C o o k J o a n a 2010, Meditation in Modern Buddhism: Renunciation and Change in Thai Monastic Life, University Press, Cambridge. 
C o s mides Le d a, To ob y Jo h n 1992, Cognitive Adaptations for Social Change, [w:] L. Cosmides, J.H. Barkow, J. Tooby (red.), The Adapted Mind: Evolutionary Psychology and the Generation of Culture, Oxford University Press, New York-Oxford, s. 163-228.

Cosmides Led a, To oby Joh n 2005, Neurocognitive Adaptations Designed for Social Exchange, [w:] D.M. Buss (red.), The Handbook of Evolutionary Psychology, John Wiley \& Sons, Inc. Hoboken, NJ, s. 584-627.

Cross Susan E., UskulAyse K., Berna Gerçek-Swing, Zeynep Sunbay, Cansu Alözkan, Ceren Günsoy, Bilge Ataca, Zahide Karakitapoğlu-Aygün 2014, Cultural Prototypes and Dimensions of Honor, Personality and Social Psychology Bulletin, vol. 40 , nr 2, s. 232-249.

Curry Oliver S. 2007, The Conflict-Resolution Theory of Virtue, [w:] W. Sinnott-Armstrong (red.), The Evolution of Morality: Adaptations and Innateness. Moral Psychology, MIT Press, Cambridge, Massachusetts, s. 251-262.

Curry Oliver S. 2016, Morality as Cooperation: A Problem-Centred Approach, [w:] T. Shackelford, R. Hansen (red.), The Evolution of Morality, Springer International Publishing, Cham, s. 27-51.

Curry Oliver S., Chesters Mat thew 2012, Putting Ourselves in the Other Fellow's Shoes': The role of 'Theory of Mind' in Solving Coordination Problems, Journal of Cognition and Culture, vol. 12, s. 147-159.

Curry Oliver S., Chesters Matthew J., Van Lissa Caspar J. 2019a, Mapping Morality with a Compass: Testing the Theory of 'Morality-as-Cooperation' with a New Questionnaire, Journal of Research in Personality, vol. 78, s. 106-124.

Curry Oliver S., Hare Darragh, Hepbun Cameron J., Johnson Dominic, Buhrmester Michael, Whitehouse Harvey, Macdonald David 2019b, Cooperative Conservation: Seven Ways to Save the World, Conservation Science and Practice, vol. 2, nr 1, s. 1-7.

Curry Oliver S., Mullins Daniel A., Whitehouse Harvey 2019c, Is it Good to Cooperate?: Testing the Theory of Morality-as-Cooperation in 60 Societies, Current Anthropo$\log y$, vol. 60, nr 1, s. 47-69.

Curry Oliver S., Price Michael E., Price Jade G. 2008, Patience is a Virtue: Cooperative People Have Lower Discount Rates, Personality and Individual Differences, vol. 44, nr 3, s. 780-885.

D ave N a is a rgi N. 2012, Queer Activism in India: a Story in the Anthropology of Ethics, Duke University Press, Durham.

Davey Liane, Bobocel Ramona, Son Hing Leanne, Zanna Mark 1999, Preference for the Merit Principal Scale: An Individual Difference Measure of Distributive Justice Preferences, Social Justice Research, vol. 12, nr 3, s. 223-240.DeScioli Peter 2016, The Side-Taking Hypothesis for Moral Judgment, Evolutionary Psychology, vol. 7, s. 23-27.

D e S c i o li Peter, Ka r p off R a chel 2015, People's Judgments about Classic Property Law Cases, Human Nature, vol. 26, nr 2, s. 184-209.

DeScioli Peter, Kurzban Robert 2009, Mysteries of Morality, Cognition, vol. 112, nr 2, s. 281-299.

Downie Richard S. 1965, Forgiveness, The Philosophical Quarterly, vol. 15, nr 59, s. 128-134.

D re s ch P a ul, Scheele Judith (red.) 2015, Legalism: Rules and Categories, Oxford University Press, Oxford.

D u n b a r R ob in 2016, Człowiek. Biografia, tłum. Ł. Lamża, Copernicus Center Press, Kraków.

D u rk he i m É mil e 1957 [1937], Professional Ethics and Civic Morals, Routledge, London.

D u r k h e i m É mi l e 2010 [1912], Elementarne formy życia religijnego. System totemiczny w Australii, tłum. A. Zadrożyńska, Wydawnictwo Naukowe PWN, Warszawa.

D u rkhe im Émil e 2015 [1925], Wychowanie moralne, tłum. P. Kostyło, D. Rybicka, Wydawnictwo Uniwersytetu Kazimierza Wielkiego w Bydgoszczy, Bydgoszcz.

E d el A b r a h a m 1962, Anthropology and Ethics in Common Focus, The Journal of the Royal Anthropological Institute of Great Britain and Ireland, vol. 92, nr 1, s. 55-72. 
E ibl-Eibe sfeld t Ire na s 2007, Human Ethology, Transaction Publishers, New York.

Eisenberger Robert, Lynch Patrick, Aselage Justin, Rohdieck Stephanie 2004, Who Takes the Most Revenge? Individual Differences in Negative Reciprocity Norm Endorsement, Personality and Social Psychology Bulletin, vol. 30, nr 6, s. 787-799.

E me r s o n Rich ard M. 1982, Stosunki wymiany i struktury sieci wymiany, [w:] M. Kempny, J.Szmatka (red.), Współczesne teorie wymiany społecznej. Zbiór tekstów, PWN, Warszawa, s. 396-438.

Emmons Robert A., McCullough Michael E. 2004, The Psychology of Gratitude, Oxford University Press, New York.

E n g l u nd Harri 2006, Prisoners of Freedom, University of California Press, London.

F a s s in D i d i e r A. 2012, Companion to Moral Anthropology, John Wiley \& Sons Inc., New York.

Faubion James D. 2001, Toward an Anthropology of Ethics: Foucault and the Pedagogies of Autopoiesis, Representations, vol. 74, nr 1, s. 83-104.

F a u b i o n J a mes D. 2011, An Anthropology of Ethics. New Departures in Anthropology, Cambridge University Press, Cambridge.

Feh r Ernst, F is chbacher Urs 2004, Third-Party Punishment and Social Norms, Evolution and Human Behavior, vol. 25, nr 2, s. 63-87.

Fehr Ernst, Gächter Si m on 2002, Altruistic Punishment in Humans, Nature, vol. 415, nr 6868, s. $137-140$.

Fehr Ernst, Schmidt Klaus 1999, A Theory of Fairness, Competition, and Cooperation, Quarterly Journal of Economics, vol. 114, nr 3, s. 817-868.

F is ke Al a n P., R a i Tage S. 2014, Virtuous Violence: Hurting and Killing to Create, Sustain, End, and Honor Social Relationships, Cambridge University Press, Cambridge.

For te s Me ye r 2009 [1987], Religion, Morality and the Person: Essays on Tallensi Religion, Cambridge University Press, Cambridge.

F u k u y m a Fr a n c i s 1997, Zaufanie. Kapitał społeczny a droga do dobrobytu, tłum. A. i L. Śliwa, Wydawnictwo Naukowe PWN, Warszawa-Wrocław.

Gardner Andy, Griffin Ashleigh, West Stuart 2007, Social Semantics: Altruism, Cooperation, Mutualism, Strong Reciprocity and Group Selection, Journal of Evolutionary Bio$\log y$, vol. 20, nr 2, s. 415-432.

Gardne r A ndy, We st St u a r t 2014, Inclusive Fitness: 50 Years on, Philosophical Transactions of The Royal Society B Biological Sciences, vol. 369, nr 1642, s. 1-3.

Ge hle n A rnold 2017, Moralność i hipertrofia moralności. Etyka pluralistyczna, tłum. R. Michalski, J. Rolewski, E. Paczkowska-Łagowska Wydawnictwo Naukowe Uniwersytetu Mikołaja Kopernika, Torun.

G e r t B e r n a r d 2013, Loyalty and Morality, [w:] S.V. Levinsons, P. Woodruff, J. Parker, Loyalty (red.), New York University Press, New York, s. 3-21.

Gi b b a r d All a n 1990a, Norms, Discussion, and Ritual: Evolutionary Puzzles, Ethics, vol. 100, nr 4, s. 787-802.

Gibbard Alla n 1990b, Wise Choices, Apt Feelings: A Theory of Normative Judgment, Harvard University Press, Cambridge.

Gint is H e r b e r t 2000, Strong Reciprocity and Human Sociality, Journal of Theoretical Biology, vol. 206, nr 2, s. 169-179.

G in t is He r b e r t 2007, The Evolution of Private Property, Journal of Economic Behavior \& Organization, vol. 64, nr 1, s. 1-16.

Gintis Herbert, S mith Eric, B owles Sa muel 2001, Costly Signaling and Cooperation, Journal of Theoretical Biology, vol.213, nr 1, s. 103-119.

G odfray Ch arles 1992, The Evolution of Forgiveness, Nature, vol. 355, nr 6357, s. 206-207.

G o uld n e r Alvi n W. 1992, Norma wzajemności. Preliminaria. W: M. Kempny, J. Szmatka (red.), Współczesne teorie wymiany społecznej. Zbiór tekstów, PWN, Warszawa, s. 73-106.

G r a e b e r D a vi d 2018, Dług. Pierwsze pięć tysięcy lat, tłum. B. Kuźniarz, Krytyka Polityczna, Warszawa. 
Graham Jesse, Nosek Brian A., Haidt Jonathan, Iyer Ravi, Koleva Spass e $\mathrm{n}$ a, D it t o P e t e r H. 2011, Mapping the Moral Domain, Journal of Personality and Social Psychology, vol. 101, nr 2, s. 366-385.

Gray Kurt, Schein Chelsea, Ward Adrian F. 2014, The Myth of Harmless Wrongs in Moral Cognition: Automatic Dyadic Completion from Sin to Suffering, Journal of Experimental Psychology: General, vol. 143, nr 4, s. 1600-1615.

Greene Josh u 2014, Moral Tribes, Penguin Books, New York.

Greene Josh u a 2015, The Rise of Moral Cognition, Cognition, vol. 135, nr 2, s. 39-42.

Haidt Jon athan 2007, The New Synthesis in Moral Psychology, Science, vol.316, nr 5827, s. 998-1002.

H a i d t J o n a th a n 2012, Prawy umyst. Dlaczego dobrych ludzi dzieli polityka i religia, tłum. A. NowakMłynikowska, Smak Słowa, Sopot.

Haidt Jonathan, Craig Joseph 2004, Intuitive Ethics: How Innately Prepared Intuitions Generate Culturally Variable Virtues, Daedalus, vol. 133, nr 4, s. 55-66.

Haid t Jo nath a n, C r a ig Jo se ph 2011, How Moral Foundations Theory Succeeded in Building on Sand: A Response to Suhler and Churchland, Journal of Cognitive Neuroscience, vol. 23, nr 9, s. 2117-2122.

Haidt Jo nath a n, Gra h a m Je s se 2007, When Morality Opposes Justice: Conservatives Have Moral Intuitions that Liberals May not Recognize, Social Justice Research, vol. 20, nr 1, s. 98-116.

Ha idt J o n at ha n, Ke s e b i r S e lin 2010, Morality, [w:] S. Fiske, G. Gilbert, G. Lindzey (red.), Handbook of Social Psychology, Wiley, Hoboken, s. 797-832.

Ha milt on Willi a m D. 1964, The Genetical Evolution of Social Behaviour, Journal of Theoretical Biology, vol. 7, nr 1, s. 17-52.

H a m merstein Peter (red.) 2003, Genetic and Cultural Evolution of Cooperation, MIT Press, Cambridge.

Harcourt Alexander H., de Waal Frans B.M. 1992, Coalitions and Alliances in Humans and Other Animals, Oxford University Press, Oxford.

H a r d in G a r r e t t 1968, The Tragedy of the Commons, Science, vol. 162, nr 3859, s. 1243-1248.

$\mathrm{H}$ ardy I a n C., B riffa Mark 2013, Animal Contests, Cambridge University Press, Cambridge.

Heintz Monica 2021, The Anthropology of Morality: A Dynamic and Interactionist Approach, Routledge, London.

Henrich Joseph, Boyd Robert, Bowles Samuel, Camerer Colin, Fehr Ernst, Gintis Herbert, McElreath Richard, Alvard Michael, Barr Abigail, E n s m in g e r J e a n 2005, "Economic Man" in Cross-Cultural Perspective: Behavioral Experiments in 15 Small-Scale Societies, Behavioral and Brain Sciences, vol. 28, nr 6, s. 795-855.

Henrich Natalie, Hen rich Jos eph 2007, Why Humans Cooperate: A Cultural and Evolutionary Explanation, Oxford University Press, Oxford.

Henrich Joseph, Muthukrishna Michael 2021, The Origins and Psychology of Human Cooperation, Annual Review of Psychology, vol. 72, nr 1, s. 207-240.

Herskovits Melville 2018, Economic Anthropology: A Study in Comparative Economics, Alfred A. Knopf, New York.

He y w o o d P a o lo 2015, Freedom in the Code: The Anthropology of (Double) Morality, Anthropological Theory, vol. 15, s. 200-217.

H o m a n s G e orge C. 1975a, Ogólne twierdzenia nauk społecznych, [w:] P. Sztompka (red.), Metodologiczne podstawy socjologii (wybór tekstów), Wydawnictwo Uniwersytetu Jagiellońskiego, Kraków.

Homans George C. 1975b, Zachowania społeczne jako wymiana dóbr, [w:] W. Derczyński, A. Jasińska-Kania, J. Szacki, (red.), Elementy teorii socjologicznych. Materiały do dziejów wspótczesnej socjologii zachodniej, PWN, Warszawa, s. 103-119.

Ho m a n s Ge orge C. 1992, Podstawowe procesy społeczne, [w:] M. Kempny, J. Szmatka (red.), Współczesne teorie wymiany. Zbiór tekstów, PWN, Warszawa, s. 173-229.

How ell S ig ne 1997, The Ethnography of Moralities, Routledge, London. 
Hu nt ing ford Felic it y A., Turner Angela 2013, Animal Conflict, Chapman and Hall, LondonNew York.

Inglehart Ronald, Baker Wayne E. 2000, Modernization, Cultural Change, and the Persistence of Traditional Values, American Sociological Review, vol. 65, nr 1, s. 19-51.

Ingle hart Ronald, N or r is P i p p 2009, Wzbierająca fala. Równouprawnienie ptci a zmiana kulturowa na świecie, tłum. B. Hellmann, Państwowy Instytut Wydawniczy, Warszawa.

Jarmakowski Tomasz, Jarmakowska-Kostrzanowska Lilianna 2016, Polska adaptacja kwestionariusza kodów moralnych (MFQ-PL), Psychologia Społeczna, vol. 4, nr 39, s. 489-508.

Johns on Dominic, D uffy Toft Monic a 2014, Grounds for War: The Evolution of Territorial Conflict, International Security, vol. 38, nr 3, s. 7-38.

Kahneman Daniel, Tversky A mos 2013, Prospect Theory: An Analysis of Decision under Risk, [w:] L.C. MacLean, W.T. Ziemba (red.), World Scientific Handbook of the Fundamentals of Financial Decision Making: Part I, World Scientific, New Jersey, s. 99-127.

Klenk Michael 2019, Moral Philosophy and the 'Ethical Turn' in Anthropology, Zeitschrift für Ethik und Moralphilosophie, vol. 2, nr 2, s. 331-253.

Krasnow Max M., Delton Andrew W., Cosmides Leda, Tooby John 2016, Looking under the Hood of Third-Party Punishment Reveals Design for Personal Benefit, Psychological Science, vol. 27, nr 3, s. 405-418.

$\mathrm{Ku}$ a $\mathrm{n}$ Teres a 2015, Love's Uncertainty: The Politics and Ethics of Child Rearing in Contemporary China, University of California Press, Berkeley.

Laidlaw James 2002, For an Anthropology of Ethics and Freedom, The Journal of the Royal Anthropological Institute, vol. 8, nr 2, s. 311-332.

L a i d l a w J a m e s 2013, The Subject of Virtue: An Anthropology of Ethics and Freedom, New Departures in Anthropology, Cambridge University Press, Cambridge.

Lambek Michael 2000, The Anthropology of Religion and the Quarrel between Poetry and Philosophy, Current Anthropology, vol. 41, nr 3, s. 309-320.

L a m bek Mich a el 2008, Value and Virtue, Anthropological Theory, vol. 8, nr 2, s. 133-157.

L a m bek Mich a l (red.), 2010, Ordinary Ethics: Anthropology, Language, and Action, Fordham University Press, New York.

Landowska Alina M., Della Piana Bice, Feola Rosangela 2020, Humane Entrepreneurship Model: Does Morality of Entrepreneurs Matter?, Journal of the International Council for Small Business, vol. 1, nr 3-4, s. 177-198.

L a z a r S i a n 2016, Politics beyond 'Interest': Ethics, Kinship, and the Collective Self in Argentine Labour Unions, Malinowski Memorial Lecture, London School of Economics, London.

Le a r Jo n at h a n 2015, Waiting with Coetzee, Raritan, vol. 34, nr 4, s. 1-26.

Lehmann Laurent, Keller Laurent 2006, The Evolution of Cooperation and Altruism A General Framework and a Classification of Models, Journal of Evolutionary Biology, vol. 19, nr 5, s. 1365-1376.

Le ster Rebecca J. 2005, Jesus in our Wombs: Embodying Modernity in a Mexican Convent, University of California Press, Berkeley.

Le w is D a vid 1969, Convention: A Philosophical Study, Harvard University Press, Cambridge.

$\mathrm{Li} 1 \mathrm{le} \mathrm{h}$ a m m e r Hallv a r d 2014, Minding your Business? Understanding Indifference as a Virtue, Philosophical Perspectives, vol. 28, nr 1, s.111-126.

Lieberman Debra, Tooby John, Cosmides Led a 2003, Does Morality Have a Biological Basis? An Empirical Test of the Factors Governing Moral Sentiments Relating to Incest, Proceedings of the Royal Society of London. Series B: Biological Sciences, vol. 270, nr 1517, s. 819-826.

Lieberman Debra, Tooby John, Cosmides Leda 2007, The Architecture of Human Kin Detection, Nature, vol. 445, nr 7129, s. 727-731.

L u ke s S. (1985). Marxism and Morality. Oxford University Press, New York.

Mali now ski B ron isław 1980, Zwyczaj i zbrodnia w społeczności dzikich, t. 2, PWN, Warszawa. 
Manderson Lenore, Levine Susane 2020, COVID-19, Risk, Fear, and Fall-out, Medical Anthropology, vol. 39, nr 5, s.367-370.

Marett Robert 1916, Origin and Validity in Ethics, The American Journal of Theology, vol.20, nr 4, s. 517-535.

Marett R ob e r t 1931, The Beginnings of Morals and Culture, [w:] W. Rose (red.), An Outline of Modern Knowledge, Victor Gollancz, London.

Mats u zaw a Tets u r o 2001, Primate Foundations of Human Intelligence: A View of Tool Use in Nonhuman Primates and Fossil Hominids, [w:] T. Matsuzawa (red.), Primate Origins of Human Cognition and Behavior, Springer Japan, Tokyo, s. 3-25.

Mattingly Cheryl 2012, Two Virtue Ethics and the Anthropology of Morality, Anthropological Theory, vol. 12, nr 2, s. 161-184.

Mattingly Cheryl, Thro op Jas on 2018, The Anthropology of Ethics and Morality, Annual Review of Anthropology, vol. 47, nr 1, s. 475-492.

Ma z u r All an 2005, Biosociology of Dominance and Deference, Rowman \& Littlefield, Lenham.

McElreath Richard, Boyd Robert, Richerson Peter J. 2003, Shared Norms and the Evolution of Ethnic Markers, Current Anthropology, vol. 44, nr 1, s. 122-130.

Nagel Th om as 1970, The Possibility of Altruism, Princeton University Press, Princeton.

$\mathrm{Nash}$ John F. 1950, The Bargaining Problem, Econometrica, vol. 18, nr 2, s. 155-162.

Neusner Jacob, Chilton Bruce (red.) 2008, The Golden Rule: The Ethics of Reciprocity in World Religions, Bloomsbury Publishing, London-New York.

Now a k Martin A. 2006, Five Rules for the Evolution of Cooperation, Science, vol. 314, nr 5805, s. $1560-1563$.

Ohtsubo Yohsuke, Wat a nabe Esuka 2009, Do Sincere Apologies Need to be Costly? Test of a Costly Signaling Model of Apology, Evolution and Human Behavior, vol. 30, nr 2, s. 114-123.

Ol s o n M a n c u r 2012, Logika działania zbiorowego. Dobra publiczne i teoria grup, tłum. S. Szymański, Wydawnictwo Naukowe Scholar, Warszawa.

O s t r o m E l i n o r 1990, Governing the Commons: The Evolution of Institutions for Collective Action, Cambridge University Press, New York.

O st r o m El in or 2013, Dysponowanie wspólnymi zasobami, tłum. Z. Wiankowska-Ładyka, Wolters Kluwer Polska SA, Warszawa.

O st rom Elin or, Walker J a mes (red.) 2003, Trust and Reciprocity: Interdisciplinary Lessons for Experimental Research, Russell Sage Foundation, New York.

Park Nansook, Peterson Christopher, Seligman Martin E.P. 2006, Character Strengths in Fifty-Four Nations and the Fifty US States, The Journal of Positive Psychology, vol. 1, nr 3, s. 118-129.

Pat te r s o n Th o m a s2009, Karl Marx, Anthropologist, Bloomsbury Academic, London.

Pax on He ather 2004, Making Modern Mothers: Ethics and Family Planning in Urban Greece, University of California Press, Berkeley.

Pen nock Robert, Chapman Jo n at han (red.) 1979, Compromise in Ethics, Law and Politics, t. 21, New York University Press, New York.

Petersen Michael B ang 2013, Moralization as Protection Against Exploitation: Do Individuals Without Allies Moralize More?, Evolution and Human Behavior, vol. 34, nr 2, s. 78-85.

P i a g e t J e a n 1967, Rozwój ocen moralnych dziecka, tłum. T. Kołakowska, PWN, Warszawa.

P in ke r S t e ve n 2010, The Cognitive Niche: Coevolution of Intelligence, Sociality, and Language, Proceedings of the National Academy of Sciences, vol. 107, nr 2, s. 8993-8999.

Prinz Jess e 2007, Is Morality Innate?, [w:] W. Sinnott-Armstrong (red.), Moral Psychology. The Evolution of Morality: Adaptations and Innateness, t. 1, MIT Press, Cambridge.

Rai Tage, Fiske Alan 2011, Moral Psychology is Relationship Regulation: Moral Motives for Unity, Hierarchy, Equality, and Proportionality, Psychological Review, vol. 118, nr 1, s. 57-75.

R a jt a r Małg o r z a t 2014, Zwrot etyczny i nowa antropologia moralności, $L u d$, vol. 98, s. 137-156. R awls Jo h n 1958, Justice as Fairness, The Philosophical Review, vol. 67, nr 2, s. 164-194. 
Rich ards Norvin 1988, Forgiveness, Ethics, vol. 99, nr 1, s.77-97.

Riechert Susan E. 1998, Game Theory and Animal Contests, [w:] D. Dalbosco Dell'Aglio, M. de Souza Mendonça (red.), Game Theory and Animal Behavior, Oxford University Press, Oxford, s. 64-93.

Robbins Joel 2012, Cultural Values, [w:] D. Fassin (red.), A Companion to Moral Anthropology, John Wiley \& Sons, New York, s. 117-132.

R o s e C a r ol M. 1985, Possession as the Origin of Property, The University of Chicago Law Review, vol. 52, nr 1, s. 73-88.

$\mathrm{R}$ u b in P a u 1 H. 2000, Hierarchy, Human Nature, vol. 11, nr 3, s. 259-279.

Sachs Joel L., Mueller Ulrich G., Wilcox Thomas P., Bull James J. 2004, The Evolution of Cooperation, The Quarterly Review of Biology, vol. 79, $\mathrm{nr}$ 2, s. 135-160.

Santema Peter, Schlicht Emmi, Kempenaers Bart 2019, Testing the Conditional Cooperation Model: What Can we Learn from Parents Taking Turns when Feeding Offspring?, Frontiers in Ecology and Evolution, vol. 7, nr 94, s. 1-6.

S chein Chelsea, Gray Kurt 2017, The Theory of Dyadic Morality: Reinventing Moral Judgment by Redefining Harm, Personality and Social Psychology Review, vol. 22, nr 1, s. 32-70.

$\mathrm{S} \mathrm{chwartz}$ S h a lo m 1992, Universals in the Content and Structure of Values: Theoretical Advances and Empirical Tests in 20 Countries, Advances in Experimental Social Psychology, vol. 25, s. 1-65.

Sell Aaron, Tooby John, Cosmides Led a 2009, Formidability and the Logic of Human Anger, Proceedings of the National Academy of Sciences, vol. 106, nr 35, s. 15073-15078.

S e n n e t R i ch a rd 2012, Razem. Rytualy, zalety i zasady wspótpracy, tłum. J. Dzierzgowski, Warszawskie Wydawnictwo Literackie Muza SA, Warszawa.

Sherratt Tom N., Mestert on-Gibbons Mike 2015, The Evolution of Respect for Property, Journal of Evolutionary Biology, vol. 28, nr 6, s. 1185-1202.

Shultz Susanne, Opie Christopher, Atkinson Quentin D. 2011, Stepwise Evolution of Stable Sociality in Primates, Nature, vol. 479, nr 7372, s. 219-222.

Sinnott-Armstrong Walter (red.) 2007, Moral Psychology, t. 1-3, MIT Press, Cambridge.

S ky r m s B rian 1996, Evolution of the Social Contract, Cambridge University Press, Cambridge.

S k y r m s B ri a n 2001, The Stag Hunt, Proceedings and Addresses of the American Philosophical Association, vol. 75 , $\mathrm{nr} 2$, s. 31-41.

S mith John Maynard 1982, Evolution and the Theory of Games, Cambridge University Press, Cambridge.

Smith John Maynard, Price George R. 1973, The Logic of Animal Conflict, Nature, vol. 246, nr 5427, s. 15-18.

S mith John Maynard, Szath máry Eörs 1995, The Major Transitions in Evolution, Oxford University Press, Oxford.

Sterelny Kim, Fraser B en 2017, Evolution and Moral Realism, The British Journal for the Philosophy of Science, vol. 68, nr 4, s. 981-1006.

Strassmann Joan E., Queller David C. 2014, Privatization and Property in Biology, Animal Behaviour, vol. 92, s. 305-311.

S u g d e n R o b e r t 1986, New Developments in the Theory of Choice under Uncertainty, Bulletin of Economic Research, vol. 38, nr 1, s. 1-24.

Ta le b N icolas 2001, Fooled by Randomness: The Hidden Role of Chance in the Markets and in Life, Texere, New York.

Taylor Erin 2013, Materializing Poverty: How the Poor Transform their Lives, AltaMira Press, Lanham.

To m a s ello Mi cha el 2015, Historia naturalna ludzkiego myślenia, tłum. B. Kucharzyk, R. Ociepa, Copernicus Center Press, Kraków.

To m a ello Michael 2016, A Natural History of Human Morality, Harvard University Press, Cambridge.

Tom a sello Michael, Vaish A m rish a 2013, Origins of Human Cooperation and Morality, Annual Review of Psychology, vol. 64, nr 1, s. 231-255. 
Tooby John, DeVore Irven 1987, The Reconstruction of Hominid Behavioral Evolution through Strategic Modeling, [w:] W. Kinzey (red.), The Evolution of Human Behavior: Primate Models, State University of New York Press, New York, s. 183-237.

Trivers Ro b e rt L. 1971, The Evolution of Reciprocal Altruism, The Quarterly Review of Biology, vol. 46, nr 1, s. 35-57.

von Neumann John, Morgenster n O skar 1944, Theory of Games and Economic Behavior, Princeton University Press, Princeton.

de Wa al Frans 2014, Bonobo i ateista, tłum. K. Kornas, Copernicus Center Press, Kraków.

Warneken Felix, Tom a sello Mich a el 2009, The Roots of Human Altruism, British Journal of Psychology, vol. 100, nr 3, s. 455-471.

We eden Jas on, Kurzban Robert 2013, What Predicts Religiosity? A Multinational Analysis of Reproductive and Cooperative Morals, Evolution and Human Behavior, vol. 34, nr 6, s. 440-445.

West Stuart A., Griffin A shleigh S., Gardner Andy 2007, Evolutionary Explanations for Cooperation, Current Biology, vol. 17, nr 16, s. R661-R672.

We s t e r m a r ck E d vard 1906, The Origin and Development of the Moral Ideas, vol. 2, Macmillan, London.

We ster m a r ck E dva rd 1932, Ethical Relativity, Kegan Paul, London.

Woj cis zke B ogdan, Wi e sław B a ryła 2000, Potoczne rozumienie moralności: pięć kodów etycznych i narzędzie ich pomiaru, Przegląd Psychologiczny, vol. 43, nr 4, s. 395-421.

Wong D avid B. 1984, Moral Relativity, University of California Press, Berkley-Los Angeles-London.

Yarrow Thomas, Candea Matei, Trundle Catherine, Cook Jo (red.) 2015, Detachment: Essays on the Limits of Relational Hhinking, Manchester University Press, Manchester.

Zig o n Jarrett 2008, Morality: An Anthropological Perspective, Routledge, London.

Zigon Jarrett, Throop Jas on C. 2014, Moral Experience: Introduction, Ethos, vol. 42, nr 1, s. $1-15$.

\section{ALINA LANDOWSKA}

\section{ABOUT RELATIONS BETWEEN COOPERATION AND MORALITY - TOWARDS A NEW ANTHROPOLOGY OF MORALITY}

Keywords: anthropology of morality, morality, cooperation, culture, ethics

What moral values can be considered as universal and common for all people? Theory of Moralityas-Cooperation (MAC) states that morality is a collection of biological and cultural solutions - helping kin, helping one's group, reciprocating costs and benefits, displaying 'hawkish' and 'dove-ish' traits, dividing disputed resources, and respecting prior possession - to the problems of cooperation recurrent in human social life. Regardless of culture, those solutions are investigated as morally good. Therefore, from those seven distinct types of cooperative behavior, it is possible to derive a coherent theory of morality, which anthropology has so far been lacking.

Adres Autorki:

Dr Alina Landowska

SWPS Uniwersytet Humanistycznospołeczny

ul. Chodakowska 19/31, 03-815 Warszawa

E-mail: alandowska@swps.edu.pl

ORCID: 0000-0002-7966-8243 